\section{PEMANFAATAN INTERNET}

UNTUK PERKULIAHAN

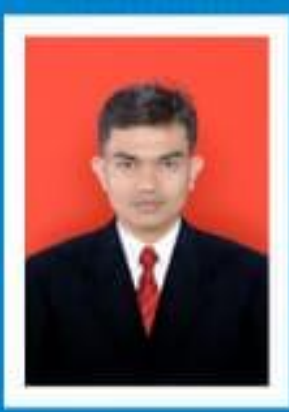

Nasrul Makdis, S.IP., MA lahir di Jorong Malus, Kec. Sangir, Kab. Solok Selatan, Sumatera Barat, 6 Mei 1977. la merupakan anak sulung dari 7 bersaudara dari pasangan Muhammad Rusli dan Nurbaiti (Almarhumah), saat ini dia seorang pustakawan dan dosen luar biasa untuk Universitas Islam Negeri (UIN) Imam Bonjol Padang. la pernah meraih penghargaan sebagai pustakawan berprestasi terbaik tingkat provinsi Sumatera Barat pada tahun 2014, 2016, dan 2018. Karya ilmiahnya meliputi kajian tentang automasi perpustakaan dan literasi informasi yang dimuat pada jurnal ilmu informasi dan perpustakaan.

Riwayat pendidikan Sekolah Dasar Negeri di Sungai Landeh, Sangir, Kab. Solok Selatan, tamat tahun 1991, MTsN Durian Tarung Padang tamat tahun 1994, MAN 1 Padang tamat tahun 1997. Setelah menyelesaikan jenjang S-1 di IAIN Imam Bonjol tahun 2004, ia mendapatkan gelar magister di bidang pendidikan Islam dari Universitas Muhammadiyah Sumatera Barat tahun 2014. la aktif dalam beberapa organisasi profesi seperti Ikatan Pustakawan Indonesia (IPI) Sumatera Barat. Selain itu, ia tercatat sebagai Sekretaris Biro Jasa Konsultasi Perpustakaan Padang dan Ketua Komunitas Senayan Library Management System (SLiMS) Pustakawan Universitas Islam Negeri (UIN) Imam Bonjol Padang, ia dapat dihubungi via HP. +6281363258111 dan alamat e-mail:makdis@uinib.ac.id

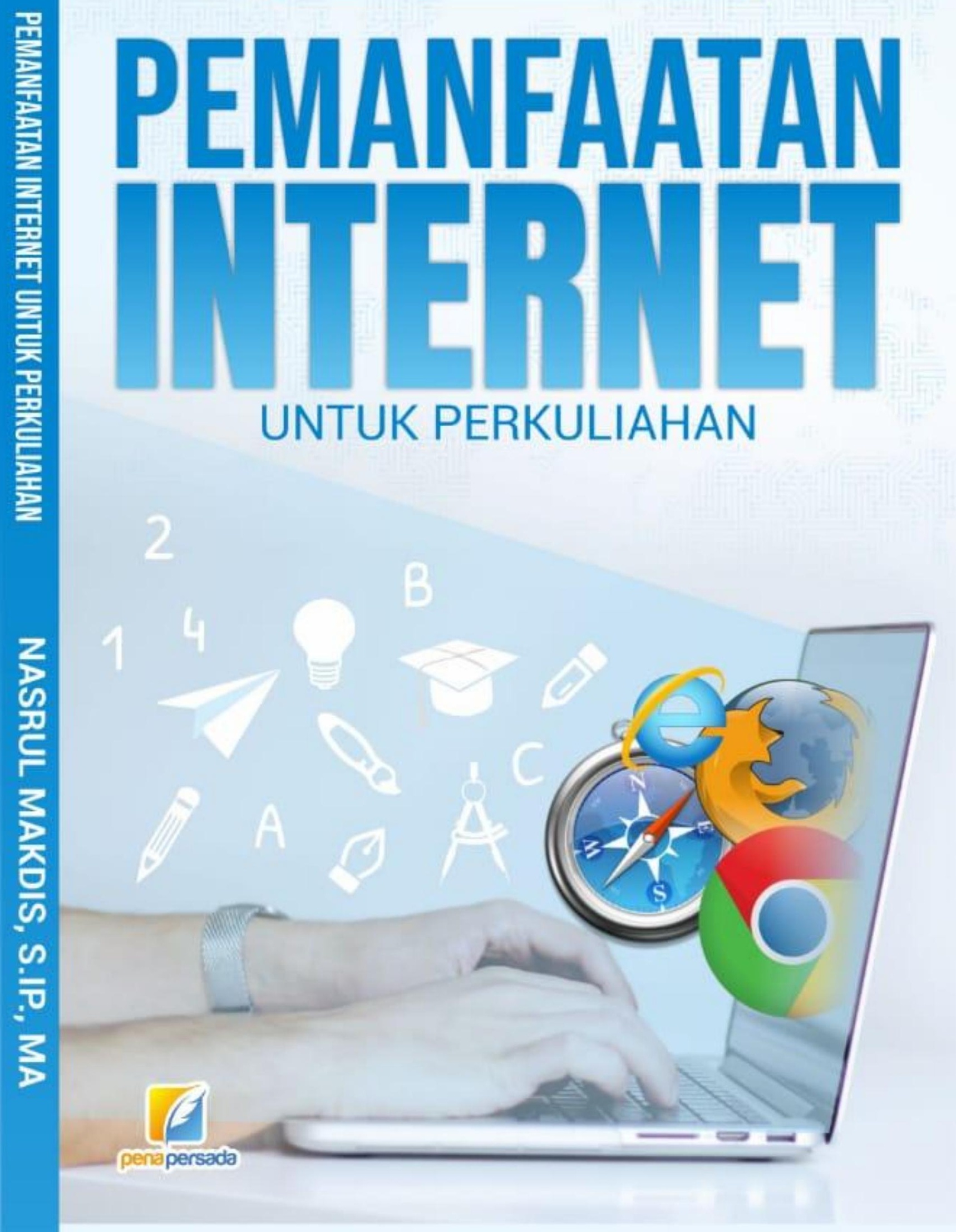




\title{
PEMANFAATAN INTERNET UNTUK PERKULIAHAN
}

\author{
Nasrul Makdis
}

penapersada

PENERBIT CV. PENA PERSADA 


\title{
PEMANFAATAN INTERNET UNTUK PERKULIAHAN
}

\author{
Penulis: \\ Nasrul Makdis \\ Editor : \\ Wiwit Kurniawan \\ ISBN : 978-623-6837-46-7 \\ Design Cover : \\ Retnani Nur Briliant \\ Layout : \\ Nisa Falahia

\section{Penerbit CV. Pena Persada} \\ Redaksi : \\ Jawa Tengah \\ Email : penerbit.penapersada@gmail.com
}

Jl. Gerilya No. 292 Purwokerto Selatan, Kab. Banyumas

Website : penapersada.com Phone : (0281) 7771388

\section{Anggota IKAPI}

All right reserved

Cetakan pertama : 2020

Hak Cipta dilindungi oleh undang-undang. Dilarang memperbanyak karya tulis ini dalam bentuk apapun tanpa izin penerbit 


\section{KATA PENGANTAR}

Internet merupakan sebagai sebuah jaringan raksasa yang menghubungkan berjuta-juta komputer di dunia tidak saja berfungsi sebagai medium untuk tukar-menukar informasi secara cepat dan murah, namun telah menjadi gudang pengetahuan yang tak ternilai harganya (Richardus Eko Indrajit, 2006:2)

Internet dapat diakses dari seluruh bagian dunia dan bersifat publik sangat membantu dalam menyebarkan dan mengumpulkan informasi. Sebagai bagian dari produk teknologi, internet berkembang pesat dan menyentuh hampir semua lini kehidupan. Hal ini memberi peluang pula pada dunia pendidikan, khususnya bagi staf pengajar dan peserta didik untuk memperoleh berbagai jenis sumber belajar. Fasilitas-fasilitas yang dimiliki oleh internet adalah sarana yang paling tepat untuk melakukan hal kolaborasi yang melibatakan banyak pihak yang dapat melewati batas ruang dan waktu.

Dalam buku ini, masalah yang diangkat adalah tentang bagaimana tingkat efektifitas pemanfaatan internet dalam mendukung kegiatan perkuliahan. Penulis menyadari bahwa buku ini masih jauh dari kata sempurna. Oleh karena itu, saran dan masukan dari pembaca adalah anugerah untuk penulis demi perbaikan di masa depan. Saya ucapkan terima kasih pada semua pihak yang telah membantu penyelesaian buku ini. Semoga buku ini dapat bermanfaat bagi semua. Terima kasih. 


\section{DAFTAR ISI}

KATA PENGANTAR ....................................................... iii

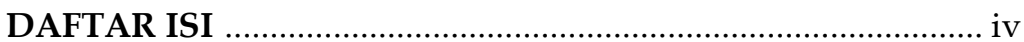

BAB 1 PENDAHULUAN .................................................... 1

A. Munculnya Era Internet.......................................... 1

B. Internat untuk Pendidikan ......................................... 2

BAB II SEJARAH INTERNET DAN PENGGUNAANYA ....... 5

A. Pengertian Internet ............................................. 5

B. Sejarah dan Perkembangan Internet ........................... 6

C. Manfaat Internet......................................................... 9

D. Fasilitas yang Tersedia di Internet................................ 12

E. Keuntungan Pencarian Informasi Melalui Internet ...... 17

F. Pemanfaatan Internet................................................. 18

G. Tempat Penggunaan Internet..................................... 18

H. Teknik Penelusuran ...................................................... 18

I. Pemanfaatan Fasilitas Internet....................................... 19

J. Jenis Informasi ........................................................... 20

BAB III INTERNET UNTUK PENDIDIKAN ........................ 21

A. Penggunaan Internet Pada Perguruan Tinggi.............. 21

B. Internet Sebagai Media Pendukung Dalam Perkuliahan.................................................................. 24

C. Faktor-Faktor yang Mempengaruhi Efektifitas

Pemanfaatan Internet dalam Mendukung Perkuliahan............................................................... 26

BAB III PEMANFAATAN INTERNET UNTUK PENDIDIKAN DAN EFEKTIVITASNYA ...................................................... 29

A. Cara Pemanfaatan Internet......................................... 29

1. Penggunaan Akses Internet ................................... 29

2. Bahan Informasi dari Internet Merupakan prioritas Utama............................................................... 30

3. Motivasi dari dosen/staf untuk mengakses informasi dari internet untuk menambah wawasan maupun untuk tugas

4. Tuntutan dari Program Studi Untuk Mencari Informasi Terbaru 
5. Kemampuan Menggunakan Komputer Secara Umum

6. Menggunakan berbagai macam mesin pencari selain google, yahoo, altavista, licos.

7. Pengetahuan Menggunakan Meta- Search Engine...38

8. Memiliki pengetahuan yang baik tentang teknik menelusur informasi di mesin pencari dengan menggunakan kriteria Boelan atau matematik .40

9. Pengetahuan yang baik tentang teknik penelusuran dengan menggunakan Kriteria Advanced Search...42

10. Kemampuan yang baik dalam memahami informasi berbahasa inggris di internet yang berhubungan dengan studi.

11. Memiliki fasilitas akses internet yang mudah .45

12. Ketersediaan Kampus memiliki fasilitas akses internet yang memadai ...............................................4

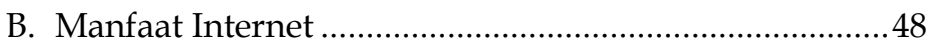

1. Bahan informasi dari internet....................................48

2. Informasi atau bahan perkuliahan sangat banyak didapat di internet.

3. Persepsi terhadap Informasi Dari Internet Sangat membantu Dalam Mendukung Studi Atau Perkuliahan .52

4. Nilai Efektifitas Pemanfaatan Internet .53

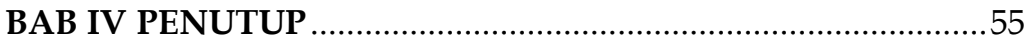

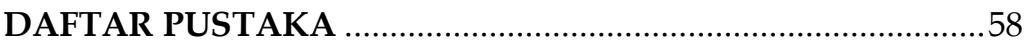


PEMANFAATAN INTERNET UNTUK PERKULIAHAN 


\section{BAB 1 \\ PENDAHULUAN}

\section{A. Munculnya Era Internet}

Internet berawal dari institusi pendidikan dan penelitian di Amerika Serikat. Penggunaan internet untuk kepentingan bisnis baru dilakukan semenjak tahun 1995. Di luar negeri, internet sering diasosiasikan dengan perguruan tinggi, sementara di Indonesia, internet lebih diasosiasikan dengan bisnis dan entertainment (Rahadjo, 2001: 1)

Sebelum adanya internet, masalah utama yang dihadapi oleh pendidikan (diseluruh dunia) adalah akses internet kepada sumber informasi. Perpustakaan yang konvensional merupakan sumber informasi yang tidak murah. Buku-buku dan jurnal harus dibeli dengan harga mahal. Pengelolaan yang baik juga tidak mudah. Sehingga akibatnya banyak tempat diberbagai lokasi di dunia yang tidak memiliki perpustakaan yang lengkap. Adanya internet memungkinkan mengakses kepada sumber informasi yang mulai tersedia banyak. Dengan kata lain, masalah akses semestinya bukan menjadi masalah lagi.

Internet dapat dianggap sebagai sumber informasi yang sangat besar. Bidang apapun yang diminati, informasinya ada di internet. Di Indonesia, masalah kelangkaan sumber informasi konvensional (perpustakaan) lebih berat dibanding dengan tempat lain. Adanya internet merupakan salah satu solusi pamungkas untuk mengatasi masalah ini.

Dalam waktu yang relatif singkat semenjak internet pertama kali terbuka penggunaanya untuk pemakaian umum pada tahun 1986, jaringan komunikasi ini merambah dengan kecepatan luar biasa keseluruh pelosok dunia tak terkecuali Indonesia. Menurut data terakhir, pada tahun 1999 lebih dari 100 juta orang menggunakan internet dan jumlah tersebut masih akan terus bertambah, seiring dengan bertambahnya 
kesadaran akan perlunya informasi dan semakin banyaknya kemudahan-kemudahan yang bisa didapat melalui internet. (Hardjito, 2002:2)

Kesempatan untuk mengakses internet juga semakin terbuka lebar bagi pengguna yang tidak memiliki komputer sendiri, dengan bermunculannya warung internet (warnet) yang tersebar dipelosok kota-kota besar. Warnet yang pada tahun 1999 di Jakarta masih bisa dihitung dengan jari, kini merebak diberbagai pelosok. ( Hardjito, 2002:1)

\section{B. Internat untuk Pendidikan}

Para akademisi merupakan salah satu pihak yang paling diuntungkan dengan kemunculan internet. Aneka referensi, jurnal, maupun hasil penelitian yang dipublikasikan melalui internet tersedia dalam jumlah yang berlimpah. Para mahasiswa tidak lagi perlu mengacak buku diperpustakaan sebagai bahan untuk mengerjakan tugas-tugas kuliah. Cukup dengan memanfaatkan search engine, materi yang relevan dapat segera ditemukan.

Internet dapat diakses dari seluruh bagian dunia dan bersifat publik sangat membantu dalam menyebarkan dan mengumpulkan informasi. Sebagai bagian dari produk teknologi, internet berkembang pesat dan menyentuh hampir semua lini kehidupan. Hal ini memberi peluang pula pada dunia pendidikan, khususnya bagi staf pengajar dan peserta didik untuk memperoleh berbagai jenis sumber belajar. Fasilitas-fasilitas yang dimiliki oleh internet adalah sarana yang paling tepat untuk melakukan hal kolaborasi yang melibatakan banyak pihak yang dapat melewati batas ruang dan waktu.

Dalam kegiatan belajar di universitas, seorang mahasiswa membiasakan diri dengan topik yang disampaikan oleh para dosen. Membaca berbagai literatur yang berkaitan dengan topik yang disampaikan oleh dosen akan memberikan pemahaman yang komprehensif dan memperluas wawasan. Seorang mahasiswa juga berupaya untuk berintegrasi dengan teknologi. Teknologi informasi sebagai perpanduan antara 
teknologi komputer dan komunikasi membuat perubahan dalam melakukan sesuatu termasuk cara dalam mengidentifikasi dan mendapatkan informasi. Sumberdaya informasi web atau internet tumbuh dan berkembang, bahkan dalam jenis tertentu melebihi jumlah yang berhasil dikumpulakan oleh perpustakaan bentuk fisik (Siregar, 1991:1)

Dengan tersedianya fasilitas-fasilitas di atas maka mahasiswa Program Studi Ilmu Keperawatan Fakultas Kedokteran Universitas Andalas Padang akan semakin mudah untuk memperoleh informasi dan ilmu pengetahuan, sehingga memungkinkan mahasiswa tersebut memiliki wawasan dan pengetahuan yang luas serta akan menghasilkan sumberdaya manusia yang berkualitas. Pokok permasalahan yang timbul adalah apakah mahasiswa Program Studi Ilmu Keperawatan Fakultas Kedokteran Universitas Andalas Padang telah memanfaatkan internet yang terdapat di lingkungan kampus Universitas Andalas Padang maupun di luar lingkungan kampus Universitas Andalas Padang dengan optimal. Apabila telah dimanfaatkan secara optimal, seberapa efektif internet dalam mendukung kegiatan perkuliahan mahasiswa program studi ilmu keperawatan fakultas kedokteran universitas andalas.

Berdasarkan uraian di atas, penulis berkeinginan untuk mengetahui efektifitas pemanfaatan internet mahasiswa Program Studi Ilmu Keperawatan Fakultas Kedokteran Universitas Andalas Padang memanfaatkan internet dalam mendukung kegiatan perkuliahan mereka. Berdasarkan latar belakang masalah di atas, masalah yang mengemuka yang perlu mendapatkan pembahasan dalam buku ini yaitu: Bagaimana tingkat efektifitas pemanfaatan internet dalam mendukung kegiatan perkuliahan oleh Program Studi Ilmu Keperawatan Fakultas Kedokteran Universitas Andalas Padang.

Dalam kajian buku ini, jenis penelitian yang digunakan adalah penelitian survei dan metode penelitian yang digunakan adalah metode deskriptif. Menurut Sugiyono (1999: 112) 
mengatakan bahwa metode deskriptif adalah metode yang digunakan untuk menganalisa data dengan cara mendiskripsikan atau menggambarkan data yang telah terkumpul sebagaimana adanya tanpa bermaksud membuat kesimpulan yang berlaku untuk umum atau generalisasi.

Pembahasan utama buku ini adalah tentang efektif penggunaan internet guna mendukung perkuliahan yang mencakup aspek keterpakaian informasi, motivasi, pengetahuan tentang internet, ketersediaan fasilitas serta persepsi terhadap informasi internet. 


\section{BAB II \\ SEJARAH INTERNET DAN \\ PENGGUNAANYA}

\section{A. Pengertian Internet}

Internet merupakan sebagai sebuah jaringan raksasa yang menghubungkan berjuta-juta komputer di dunia tidak saja berfungsi sebagai medium untuk tukar-menukar informasi secara cepat dan murah, namun telah menjadi gudang pengetahuan yang tak ternilai harganya (Richardus Eko Indrajit, 2006:2)

Internet merupakan singkatan dari internet connected network. Internet adalah sebuah sistem komunikasi yang mampu menghubungkan jaringan-jaringan komputer di seluruh dunia, berbagai jenis komputer dengan spesifikasi yang berbeda-beda dapat saling berkomunikasi melalui internet, beberapa bentuk jaringan-jaringan yang berbeda dapat saling bertukar informasi dan data melalui internet menggunakan seperangkat aturan yang disebut Protokol TCP/IP. (Ramadhan, 2005: 1)

Sedangkan menurut Febrian (2001: 20) internet adalah suatu jaringan antar komputer yang saling dihubungkan. Media penghubung tersebut bisa melalui kabel, kanal satelit maupun frekuensi radio, sehingga komputer-komputer yang saling berhubungan tersebut dapat saling berkomunikasi.

Dari defenisi di atas dapat disimpulkan bahwa internet berasal dari sebuah jaringan komputer yang terdiri dari beberapa komputer yang dihubungkan dengan menggunakan kabel, sehingga membentuk sebuah jaringan. Selanjutnya jaringan yang telah terbentuk tersebut saling dihubungkan, sehingga membentuk inter-network yang dikenal dengan internet. Internet adalah jaringan komputer yang saling terhubung ke seluruh dunia tanpa mengenal batas teritorial, hukum dan budaya. Secara fisik internet dianalogikan sebagai 
jaring laba-laba (the web) yang menyelimuti bola dunia dan terdiri dari titik-titik (node) yang saling berhubungan.

Lani Sidharta dalam menjelaskan bahwa :

Walaupun secara fisik internet adalah interkoneksi antar jaringan komputer, namun secara umum internet harus dipandang sebagai sumber daya informasi. Isi internet adalah informasi, dapat dibayangkan sebagai suatu database atau perpustakaan multimedia yang sangat besar dan lengkap. Bahkan Internet dipandang sebagai dunia dalam bentuk lain (maya) karena hampir seluruh aspek kehidupan di dunia nyata ada di internet seperti bisnis, hiburan, olahraga, politik dan lain sebagainya. (Suhardjo, 2001:1)

Dari uraian di atas dapat disimpulkan bahwa internet tidak hanya dipandang sebagai interkoneksi antar jaringan, tetapi juga dapat dipandang sebagai suatu database ataupun perpustakaan multimedia yang berisikan informasi yang besar, lengkap dan mutakhir serta berorientasi terhadap manusia. Internet juga memberikan kesempatan yang sama kepada setiap pemakai di seluruh dunia untuk berkomunikasi, serta memakai secara bersama-sama sumberdaya informasi di dalamnya. Internet juga telah mengubah cara kerja manusia dan dapat dipastikan akan mengubah cara manusia berinteraksi dengan dunia di sekitarnya.

\section{B. Sejarah dan Perkembangan Internet}

Sejarah Internet berawal pada akhir dekade 60-an saat United States Department of Defense (DoD) memerlukan standart baru untuk komunikasi Internetworking, yaitu merupakan standart yang mampu menghubungkan segala jenis komputer di DoD dengan komputer milik kontraktor militer, organisasi penelitian dan peneliti ilmiah di universitas. Jaringan ini harus kuat, aman dan tahan terhadap kerusakan sehingga mampu beroperasi di dalam kondisi minimum akibat bencana atau perang Drew Heywood dalam (Suhardjo, 2001 : 1). 
Internet berasal dari jaringan komputer yang dibentuk pada tahun 1969. Jaringan ini disebut dengan ARPAnet (Advanced Research Projects Administration), yaitu jaringan komputer yang dibentuk oleh Departemen Pertahanan Amerika Serikat dan dibiayai oleh Departement of Defense (DOD). Internet merupakan jaringan yang dapat diandalkan untuk menghubungkan DOD dengan kontraktor penelitian militer, termasuk juga sejumlah besar universitas yang melakukan penelitian dengan dana militer.

Tahun 1969 Advanced Research Project Agency (ARPA) dibentuk dan bertugas untuk melakukan penelitian jaringan komputer. Jaringan pertama yang dibangun menghubungkan empat tempat yaitu : UCLA, UCSB, Utah dan SRI International. Hingga tahun 1972 jaringan ini telah menghubungkan lebih dari 20 host. ARPANet kemudian menjadi backbone Internetworking institusi pendidikan, penelitian, industri dan kontraktor yang berkaitan dengan jaringan militer (MILNet). Pada tahun 1980 ARPAnet digantikan oleh jaringan militer baru yaitu Defense Data Network dan NSFnet (National Science Foundation). NSFnet adalah sebuah jaringan komputer dari kalangan ilmuwan dan akademis yang dibiayai oleh National Science Foundation.

Pada tahun 1986 internet dipublikasikan untuk penggunaan secara umum. Internet berkembang dengan kecepatan yang sangat tinggi ke seluruh dunia. Berdasarkan data dari Asosiasi Penyelenggaraan Jasa Internet Indonesia (APJIl), jumlah pelanggan yang ada pada tahun 2000 adalah 384.000. Sedangkan pengguna internet adalah sebanyak 1.450 .000 orang. Pertumbuhan tertinggi yang terjadi dari tahun 1996 sampai 2000, terjadi antara tahun 1998-1999. Selanjutnya Andrew S. Tanenbaum dalam menyatakan :

Andil besar dalam perwujudan internet adalah tergabungnya jaringan regional, seperti SPAN (jaringan fisika energi tinggi), BITNET (jaringan mainframe IBM), EARN (jaringan akademis Eropa dan digunakan pula di Eropa Timur) dan ditambah dengan sejumlah link 
transatlantik yang beroperasi pada 64 Kbps- 2 Mbps pada tahun 1988. (Suhardjo, $2001: 3$ )

Dari pernyataan di atas dapat disimpulkan bahwa, kemajuan internet tidak terlepas dari kerjasama beberapa pihak (organisasi) yang saling berperan untuk menjadikan internet semakin berkembang dan mampu memenuhi kebutuhan manusia, terutama kebutuhan manusia terhadap informasi.

Internet telah mengubah dunia informasi menjadi lebih maju. Dalam beberapa tahun terakhir ini penggunaan internet semakin meluas, termasuk di Indonesia. Internet sebagai jaringan dari jaringan-jaringan yang dengan bebas mempertukarkan informasi dan menghubungkan ribuan jaringan di seluruh dunia telah berkembang dengan pesat. Saat ini diperkirakan lebih dari 16 juta komputer host terdapat di dalam internet. Jumlah sistem di dalam internet bertumbuh lebih dari $70 \%$ setiap tahun dan populasi online tumbuh empat atau lima kali di tahun 2000.

Andrew S. Tanenbaum dalam menjelaskan bahwa perkembangan internet adalah sebagai berikut :

Akhir 1990 internet telah berkembang menjadi 3 ribu jaringan dan 200 ribu komputer. Tahun 1992 host kesatu juta terhubung ke internet dan tahun 1995 terdapat ratusan jaringan menengah regional, puluhan ribu LAN, jutaan host dan pengguna. Pertumbuhan internet ini mencapai dua kali lipat setiap tahun (data penelitian Paxton, 1996). Kini perkembangan internet yang paling populer adalah internet mampu menampilkan tidak hanya teks namun juga grafik (gambar, foto, animasi), suara, video dan dimensi virtual (3D). Diperkirakan pada akhir 1998 telah lebih dari 10 juta website dibangun oleh institusi pendidikan, bisnis, pemerintahan, media massa, hiburan, militer dan sebagainya dengan pengguna lebih dari 100 juta. (Suhardjo, 2001: 4) 
Dari uraian di atas dapat disimpulkan bahwa perkembangan internet sangat cepat dan pesat, dimana pertumbuhan pengguna internet mampu mencapai dua kali lipat setiap tahun. Pertumbuhan pengguna internet tersebut diikuti juga oleh perkembangan fasilitas yang terdapat pada internet.

Penggunaan internet juga didukung oleh berbagai perkakas yang telah dikembangkan sehingga memberikan kemudahan dalam penciptaan, penyebaran, pengenalan dan penggunaan sumberdaya jaringan. Perkakas-perkakas tersebut memungkinkan pengguna untuk berkomunikasi secara elektronik dan menerbitkan sumberdaya sendiri. Dalam proses penyebaran informasi ilmiah, seorang peneliti dapat menggunakan internet untuk menjangkau audiens yang lebih luas.

\section{Manfaat Internet}

Internet merupakan suatu sarana pendukung dalam menciptakan keberhasilan dalam segala bidang, seperti pada bidang akademik, bisnis, politik dan lain sebagainya. Menurut Nasution 2004: 8) ada beberapa manfaat dari penggunaan internet yaitu:

1. Komunikasi interaktif

Internet memungkinkan terciptanya komunikasi yang cepat antara seorang pengguna dengan pengguna lainnya tanpa mengenal batas ruang dan waktu, selain hal tersebut internet juga dapat menghemat biaya komunikasi yang dikeluarkan. Aplikasi pada internet yang dapat digunakan sebagai alat komunikasi adalah sebagai berikut : e-mail, Video Conferencing, internet relay chat dan internet phone.

2. Akses ke pakar

Seorang pengguna ataupun mahasiswa dapat dengan mudah belajar kepada para ahli (pakar) pada bidang ilmu tertentu. Para ahli (pakar) banyak yang dengan senang hati menjawab pertanyaan yang dikirimkan oleh audiens.

3. Akses ke perpustakaan

Koleksi perpustakaan tidak terbatas lagi pada koleksi buku dan jurnal tercetak, akan tetapi telah menjadi pusat penyebaran informasi maupun pangkalan data penelitian dan aktivitas yang ada di universitas. 
4. Sebagai alat bantu penelitian dan pengembangan pengetahuan

Melalui jaringan internet, para peneliti yang berkecimpung dalam dunia penelitian dapat membuat asosiasi di antara mereka untuk dapat saling berkomunikasi.

5. Pertukaran data

6. Kolaborasi

Kolaborasi yang dimaksud adalah menyelesaikan pekerjaan secara bersama-sama. Anggota dapat terdiri dari berbagai bidang ilmu dan tersebar di berbagai negara di dunia. Internet merupakan media yang sangat membantu suatu kolaborasi yang biasanya terhambat oleh ruang dan waktu.

Menurut Oetomo (2001 : 12) internet menawarkan bebagai manfaat dalam bidang pendidikan, seperti :

1. Kemampuan dan kecepatan dalam komunikasi; bahkan sekarang telah dimungkinkan menggunakan peralatan berbasis multimedia dengan biaya yang relatif murah, sehingga dimungkinkan untuk melangsungkan pendidikan dan komunikasi jarak jauh antara peserta didik dengan para pendidik

2. Ketersediaan informasi yang up-to date telah mendorong tumbuhnya motivasi untuk membaca dan mengikuti perkembangan ilmu pengetahuan dan teknologi (iptek) yang terjadi diberbagai belahan dunia.

3. Adanya fasilitas untuk membentuk dan melangsungkan diskusi kelompok (Newsgroup) sehingga akan mendorong peningkatan intensitas kajian Iptek.

4. Melalui web, pendidikan proses belajar dapat dilakukan secara dinamis dan tidak tergantung waktu dan ruang pertemuan. Semua materi belajar dapat diperoleh dengan mudah pada situs-situs pendidikan yang tersedia, dengan demikian biaya pendidikan dapat ditekan serendah mungkin karena itu peserta didik tidak perlu menanggung biaya gedung.

5. Melalui e-mail, konsultasi dapat dilakukan secara pribadi antar peserta didik dengan pendidik ataupun dengan rekan lainnya. 
Sedangkan menurut (Siregar, $2004: 59)$ fungsi internet dapat dibagi menjadi empat tingkatan yaitu tingkat komunikasi dasar, komunikasi interaktif dan sumberdaya dan layanan informasi lanjutan.

1. Komunikasi dasar

Pada tingkat komunikasi dasar, surat elektronik (email) adalah jenis yang paling populer dari aktivitas dalam internet. Jutaan pesan dipertukarkan setiap hari dari seluruh dunia, melalui sistem surat elektronik menggantikan fungsi pengiriman tradisional melalui pos. Fungsi lainnya adalah forum dan obrolan online. Internet memungkinan ribuan forum masyarakat beroperasi layaknya papan pengumuman elektronik yang lebih dikenal dengan nama BBS (Buletin Board System). Disamping itu percakapan elektronik juga dapat dilakukan di antara sesama pengguna.

2. Komunikasi interaktif

Pada komunikasi interaktif yang paling banyak dilakukan adalah temu-balik Informasi (Information retrievel). Fungsi ini layaknya penyediaan hubungan remote logon (Telnet) interaktif ke sistem komputer lain seperti Dialog Information Service. Contoh lain komunikasi Interaktif adalah penelusuran katalog online dan pangkalan data perusahaan, pemerintah dan organisasi nirlaba lain yang dibuka untuk umum.

3. Sumberdaya dan layanan informasi lanjutan

Pada tingkat ini fungsi yang relevan adalah pengiriman berkas elektronik yang disebut FTP yang mendefenisikan protokol untuk mentransfer berkas dari satu komputer ke komputer lainnya. Sebagai tambahan, kepada FTP terdapat beberapa program (tools) yang berfungsi untuk mengakses, mengidentifikasi dan menemubalik informasi yang telah dikembangkan. Programprogram yang dimaksud di atas disebut dengan RADAR (Resource, Access, Discovery dan Retrieval), termasuk di antaranya adalah Gopher,World Wide Web (WWW) dan Archie. Gopher, World Wide Web (WWW) memungkinkan pengguna mengakses dan menemu-balik berbagai sumberdaya yang tersedia, sedangkan Archie dapat mengidentifikasi lokasi komputer yang memiliki berkas yang memilki teks, citra, perangkat lunak atau data yang tersedia bagi umum untuk di download. 
Dari ketiga uraian di atas dapat disimpulkan bahwa melalui internet seorang pengguna dapat melakukan komunikasi dengan pihak lain dan memperoleh informasi dengan cepat dengan biaya yang rendah. Melalui internet pendidikan jarak jauh juga dapat dilaksanakan, sehingga dapat memberikan keuntungan bagi mahasiswa dan para staf pengajar. Keuntungan yang dapat diperoleh adalah adanya penghematan terhadap ruang, waktu dan biaya bagi kedua belah pihak. Selanjutnya Selain berfungsi sebagai alat komunikasi dasar, seperti e-mail, internet juga berfungsi melakukan temu-balik informasi dan melakukan pengiriman berkas-berkas dalam bentuk elektronik.

\section{Fasilitas yang Tersedia di Internet}

Pengertian fasilitas adalah sesuatu yang dapat membantu memudahkan pekerjaan, tugas dan sebagainya. Sehingga dapat disimpulkan bahwa fasilitas internet adalah segala sesuatu yang dapat membantu memudahkan pengguna dalam memanfaatkan internet. (Kamus Bahasa Indonesia, 2002:415)

Menurut (Margatan, 2004:18) peralatan yang dibutuhkan agar dapat ter- hubungan ke internet adalah :

1. Account Internet

2. Komputer

3. Modem

4. Program komunikasi sederhana

5. Informasi parameter komunikasi

6. Nama login

7. Password

Komputer merupakan salah satu peralatan yang memiliki peranan penting bagi pengguna dalam melakukan hubungan dengan internet. Menurut (Oetomo, 2002:27) sistem komputer terdiri dari :

1. Hardware merupakan perangkat yang dapat dipegang dan diraba. Perangkat keras komputer yang secara umum terdiri dari peralatan input, proses, output dan storage. 
2. Software merupakan perangkat yang dapat dilihat oleh mata, tetapi tidak dapat diraba. Istilah perangkat lunak juga sering digunakan untuk menunjukkan semua sistem, bahasa dan progaram yang dapat dipakai dalam sistem komputer. Dalam pengertian yang sempit, istilah ini menunjukkan pada data dan program yang dapat mempermudah pemakai dari berbagai jenis komputer untuk mendayagunakan perangkat keras tersebut untuk menghasilkan informasi.

3. Data merupakan bentuk jamak dari kata datum yang berarti fakta, data adalah istilah umum yang mewakili angka, karakter dan simbol-simbol lain yang berfungsi sebagai masukan untuk proses pengolahan data. Data yang mewakili simbol-simbol bukan merupakan informasi kecuali dalam bahasa pengertian tertentu.

4. Program merupakan kata, ekspresi, pernyataan atau kombinasinya yang disusun dan dirangkai menjadi kesatuan prosedur dengan menggunakan bahasa pemrograman yang mengimplementasikan urutan langkah untuk menyelesaikan suatu masalah pengolahan data yang akan dieksekusi oleh komputer.

5. Sumber daya manusia adalah perangkat manusia yang sering disebut dengan brainware atau lifeware atau perangkat akal. Manusia memegang peranan penting khususnya dalam pengoperasian komputer. Tanpa manusia yang mengoperasikan, perangkat keras keras komputer tidak akan berguna. Disamping itu, manusia memiliki peran yang lebih penting lagi, yaitu sebagai penganalisis, penemu teknik pemecah masalah dan pengambil keputusan.

6. Prosedur-prosedur merupakan tata aturan yang disusun untuk mengoperasikan, mengendalikan dan mengamankan sistem komputer.

7. Listrik merupakan salah satu sumber daya yang diperlukan untuk mengoperasikan perangkat komputer.

Fasilitas yang terdapat pada internet cukup banyak, fasilitas tersebut dapat memberikan dukungan pada bidang militer, pendidikan, politik, maupun bisnis. Fasilitas-fasilitas tersebut adalah : e-mail, Telnet, Gopher, Mailing List, Newsgroup, File Transfer Protocol (FTP), World Wide Web dan Internet relay chat. 